\title{
ECONOMICS
}

\section{JAPAN'S ECONOMIC RECOVERY: INSIGHTS FROM MULTI-REGION DYNAMICS}

\author{
by
}

Rod Tyers

Business School

The University of Western Australia and Australian National University

Australia

\author{
and \\ Ying Zhang \\ Business School \\ The University of Western Australia
}

DISCUSSION PAPER 11.13 


\title{
Japan's Economic Recovery: Insights from Multi-Region Dynamics *
}

\author{
Rod Tyers \\ Business School \\ University of Western Australia and \\ Centre for Applied Macroeconomics (CAMA) \\ College of Business and Economics \\ Australian National University \\ Australia \\ and \\ Ying Zhang \\ Business School, \\ University of Western Australia \\ Australia
}

June 2011

\section{DISCUSSION PAPER 11.13}

* Corresponding author. Address: Department of Economics, Business School, University of Western Australia, Perth, WA 6009, Australia. This is a more complete draft of a paper presented at the conference commemorating 30 years of the Australia-Japan Research Centre, 28-29 March, 2011. It is a product of the project on Modelling the Impact of Japan's Economy on Australia, financed by the Australia-Japan Foundation. For encouragement and useful comments on an earlier draft, thanks are due to Aki Asano, Jenny Corbett, Peter Robertson, Andy Stoeckel, Takatoshi Ito, Sisira Jayasuriya and other participants at the above mentioned conference. For data gathering we also thank Nagulan Siritharan and Tsun Se Cheong.

Email Address: rod.tyers@uwa.edu.au (Rod Tyers), ying.zhang@uwa.edu.au (Ying Zhang) 


\begin{abstract}
Despite its key contribution to global economic growth through the 1960s and 1970s, in recent decades the rise of China has seen the importance of Japan recede from the public discourse. This is notwithstanding its continuing key role as global investor and trading partner. Yet this role has been threatened by a tendency for its economy to stagnate since the 1990s and by the tragic earthquake of 2011, both of which have implications for global economic performance. This paper briefly reviews the many claimed sources of Japan's stagnation and then analyses the sources of recovery along with the implications of the 3-11 disaster, using a multi-region global dynamic model. Both demand and supply side determinants prove important though it is shown that a key future role will be played by the performance of Japan's services sector and of the industrial policies that affect it.
\end{abstract}

Keywords: Japan's Stagnation, Earthquake, Productivity, Real exchange rate, Dynamic CGE modelling 


\section{Introduction}

Numerous explanations have been offered for Japan's economic slowdown since the 1990s. These include its responses to external pressure that allowed substantial real appreciations against the US (McKinnon and Ohno 2001, Corbett and Ito 2010), the high productivity growth in its near neighbour, China, diverting investment funds abroad, labour force contraction due to low and declining fertility combined with resistance to immigration (Aloy and Gente 2009), deflation and the liquidity trap since the early 1990s (Krugman 1998, Bayoumi 2001, Hoshi and Kashyap 2004, Hamao et al. 2007, Koo 2009), the exhaustion of “catch-up” productivity growth (Saito 2000, Hayashi and Prescott 2002), and an inefficient and imperfectly competitive services sector (Clark 1978, Kay and Clark 2005, Fukao 2010a). Despite signs of recovery in the early 2000s, Japan’s economy was hurt disproportionately by the global financial crisis of 2008 and, not long after that, by the 3-11 earthquake and tsunami. Early in the second decade of this millennium, its benchmark performance is therefore well above current levels and a path to recovery must be charted.

This paper first briefly reviews the now extensive literature on Japan's slow growth in recent decades before drawing insights from the representation of Japan in a real dynamic model of the global economy in which growth stems from demographic change and the accumulation of physical and human capital. Supply side stories about recent poor performance (productivity “catch-up exhaustion”, technical inefficiency in services and demographic changes) are readily represented in this context yet demand side shocks are also included, via changes in risk premia, financial sector productivity and shifts in consumption-saving preferences. The model is used to derive elasticities of Japan's performance to these many determinants with a view to identifying the policy levers to which its eventual recovery will be most sensitive.

The section to follow discusses Japan's slowdown during the past two decades and briefly reviews the many economic stories offered to explain it. In Section 4 a dynamic global model is introduced to estimate the most sensitive determinants of recovery. Section 5 summarises the simulation results and highlights the main conclusions. Section 6 briefly applies the same method to an assessment of the 3-11 earthquake and a short summary is offered in Section 7. 


\section{Slowdown Stories}

The pattern of Japan's nominal and real GDP growth is shown in Figure 1. There is no mistaking the slowdown during the 90s and the evident relative stagnation survives measurement in terms of output per person and per worker or real consumption per person. ${ }^{1}$ A weakness of the extensive and high-quality literature on Japan's “lost decades” is that it only rarely includes a global context. Critically, while Japan's economy was slowing, that of its near neighbour, China, was expanding rapidly. With this “changing of the guard”, the net economic effects of Japan's slowdown on major trading partners were rendered less perceptible. Nonetheless, while Japan's share of world trade has declined during the past two decades, its long history of high saving and current account surpluses has left it by far the dominant Asian capital owner abroad.

There are numerous surveys of the literature on Japan's economic performance of recent decades, ranging from the very general (The Economist 2010) to the more deeply analytical (Boltho and Corbett 2000, Miyao 2006, Horioka 2006, Tyers and Corbett 2011). The stories they cover can be divided between those emphasising supply side causes (productivity and labour supply) and those emphasising demand side shocks (financial failures and monetary policy). Both literatures are large and persuasive. Consider first the supply side stories.

\footnotetext{
${ }^{1}$ Real output per worker does best since the labour force has declined, but real consumption per person has been static for two decades. See Tyers (2011).
} 
The exhaustion of "catch-up" tradable productivity growth and service inefficiency

Japan's very fast expansion from the 1950s to the 1970s depended significantly on the use of technologies available from abroad. As it approached the global technical frontier, further opportunities for such growth diminished (Lincoln 1988). Subsequent productivity growth would then depend on Japan's contribution to the advancement of this common technical frontier, reducing its GDP growth potential to no more than 2\% per year (Yoshikawa 2000). Supply siders and real business cycle specialists approach Japan’s “lost decade” of the 1990s with emphasis on the underlying productivity slowdown, treating it as exogenous (see, for example, Hayashi and Prescott 2002, Morana 2004, Kobayashi and Inada 2005). The sharpness of Japan's growth decline can be further explained by a delay in the recognition of this diminished underlying potential and therefore over-optimistic capital accumulation through the 1980s and early 1990s (Wilson 2000, Beaudry and Portier 2005, 2006, 2007). The arrival of more modest expectations then saw a loss in capital value and a decline in both investment and consumption (Ramaswamy and Rendu, 1999).

The catch-up tradable productivity growth period was one of outstanding economic performance which disguised Japan's comparatively inefficient services sector. As Figure 2 shows, even after the early 1970s and through 1989, manufacturing productivity was still growing at about 3.4 per cent per year. The labour force was still expanding then, allowing GDP growth to average 4.5 per cent per year. Even Japan's services sector was registering positive, if slow, productivity growth until the end of the 1980s. This stagnated completely thereafter. By comparison with other industrialised countries, Japan's services are riven with monopolies and oligopolies sustained at least in part by policy induced high entry and exit costs (Imai and Kawage 2000, Fukao 2010a, esp. Figure 10). Possibly as a consequence, service industries have been comparatively slow to adopt information technology innovations and have had comparatively low rates of "intangible” investment (Fukao 2010a: Table 1). Yet the comparatively poor performance of Japan's service industries is not new, as reference to it by Clark (1978) and Hirschmeier and Yui (1981) attests. Solutions have been slow to appear, however, since they tear at Japan’s cultural fabric (Kay and Clark 2005). There is even the argument that these narrowly defined inefficiencies are, or might potentially be, net welfare improving in a Japanese context (Gadir 2009).

Nonetheless, the oligopolies and entry restrictions cause a substantial cost burden while at the same time raising rents that add to corporate saving - now the primary source of Japan’s 
current account surplus (IMF 2006). ${ }^{2}$ The result is that growth in consumption expenditure is constrained by a high pure profit share and a tradition of financing investment from retained earnings so that dividend payments are low. Household owners therefore do not have the opportunity to commit this income to consumption. Thus, following manufacturing productivity catch-up, further growth is constrained by high service costs and slow consumption growth. ${ }^{3}$

\section{Labour force contraction:}

Adding demographic behaviour to neoclassical growth models tends to yield the standard Solow-Swan growth model story - that slower population growth slows the growth rate of GDP but raises labour's marginal product and hence the growth rate of per capita income (Pitchford 1974, Tyers and Shi 2007). For economies that are initially young, this per capita income boost can also come from the "demographic dividend", due to a rising labour force relative to population. In Japan's case, however, there are no remaining gains from reduced youth dependency and the age distribution effect is negative - the labour force is declining faster than the population and so dependency is increasing (Golley and Tyers 2011). We could call this an inverse demographic dividend. ${ }^{4}$ While this effect might be sufficient to cause real income per capita to stagnate, there are related factors that have a significant secondary influence. Beaudry et al. (2005) suggest slower labour force growth accommodates better training and hence productivity growth, thus offsetting the negative demographic dividend. But there are also negative related effects. Aloy and Gente (2009), for example, emphasise the negative effects of the rise in labour costs due to demographic change. There is also the relative inflexibility of already trained older workers and therefore the more substantial matching problems that arise in labour markets through time. And then there is the associated slowing of home markets for frontier products sought by the young, which in turn weakens incentives for productivity-enhancing private investment. These negative factors, combined with Japan's inverse demographic dividend, could be behind the

\footnotetext{
${ }^{2}$ More recent evidence of a highly concentrated and protected corporate structure appears in the wake of the global financial crisis, during which diversity of firm performance actually fell in Japan while it rose substantially in the US. See Hamao et al. (2007).

${ }^{3}$ This, and related issues, are addressed in multi-region modelling studies that include those by Brown et al. (1996), Dee et al. (2000).

${ }^{4}$ Since the declines in Japan's labour force have not been even partially offset by increasing immigration, there may also be a loss of opportunity to raise productivity by this means (Peri 2010).
} 
productivity and labour supply issues that complement the productivity story in explaining the stagnation in the highly aggregated VECM analysis by Morana (2004).

\section{Domestic demand side stories}

It is well understood that Japanese monetary policy has, during some periods at least, targeted the Yen-dollar rate while at the same time the Bank of Japan has come under substantial pressure from the US for Yen appreciation. ${ }^{5}$ The Plaza Accord is the most famous instance, though it was followed by the formalisation of this pressure via the US Exchange Rates and International Economic Policy Coordination Act of 1988. While this pressure was relaxed at least for a period in the 2000s to allow a depreciation (Taylor 2006, 2007), the appreciations that had gone before were immense, as indicated in Figure 3. Japan's underlying real exchange rate appreciated by 74 per cent after the Plaza Accord and by a further 42 per cent during the early 1990s. Even though these were subsequently reversed, their large size reduced the competitiveness of Japan's tradable industries, which had hitherto been the primary source of its economic growth. Indeed, they are said to have led to periods of endaka fukyo, or strong Yen induced recessions (Hamada and Okada 2009, Obstfeld 2009).

The largest of the real appreciations occurred in response to an explicit strong Yen policy, which invited a slowdown in Japan's net financial outflows. ${ }^{6}$ Despite a subsequent surge in investment that might have been expected to embody technical improvements, this coincided with the productivity slowdown discussed above. The rise in home investment was financed mainly by home saving, so it cut Japan's current account surpluses and hence the proportions of GDP being spent domestically, increasing home relative to foreign prices.

Other things equal such a surge in investment might be considered positive for home activity and employment, even given the expectation that it would be temporary. But this must be traded off against the broader implications of the source of the impending appreciation, namely an associated monetary contraction. Beyond reducing the risk premium on home investment, the announcement of a unilateral nominal appreciation to a forward looking market foreshadows an eventual deflation and therefore unemployment and a loss of income. That these consequences were not observed in Japan for some years beyond the Plaza Accord

\footnotetext{
${ }^{5}$ See Henning (2008), especially Chapters 3-4.

${ }^{6}$ This slowdown in outflows was almost entirely private since changes in the central banks' stock of foreign reserves did not fall in this period. The statement of a strong Yen policy was enough to change private expectations and induce a refocusing of investment domestically.
} 
suggests, at minimum, that the temporary nature of the investment surge was not anticipated. Once it was observed, however, it appears to have increased the aversion of Japanese savers to real appreciation risks and so fostered the tolerance of low saving returns at home (Goyal and McKinnon 2003).

Many studies of the demand side explanations, emphasising monetary policy and financial shocks, emerged after the collapse of economic activity in Japan in the mid-1990s. They cite contractionary policy near the end of the boom and a switch to expansionary policy that came too late and was ultimately constrained by the liquidity trap. Financial explanations include post-bubble asset price deflation, inadequate returns on saving, debt overhang and the disruption of financial intermediation due to non-performing loans (Posen 1998, Bayoumi 2001). Yet investment demand had collapsed in part due to pessimism about future returns and the liquidity trap ensured that the resulting deflation could be checked only by resort to “quantitative easing”, or central bank acquisitions of non-“money-market” instruments (Eggertson and Ostry 2005). As Figure 4 shows, investment declined even as a proportion of GDP throughout the stagnation period. Monetary expansion was seen, nonetheless, as the best exit strategy (Krugman 1998, Ball 2008). Yet this proved difficult due to political sensitivity to Yen depreciation, the US reaction discussed above and the more recent resort to quantitative easing by the US Federal reserve.

A closely related story is that of the "balance sheet” recession (Koo 2003, 2009), where solvent but heavily indebted firms use new income to de-leverage rather than finance further investment. This is of potential importance in Japan where the high average saving rate is due prominently to high corporate saving. Deleveraging is clearly one explanation for the decline in the gross domestic saving rate shown in Figure $4 .^{7}$ One difficulty with placing all explanatory eggs in this latter basket is that two decades seem too long for such a force to be the dominant influence. But the idea that saved funds disappear into balance sheet restoration rather than investment raises further questions. On the macroeconomic side, if the funds received by creditors enter consumption then, from an aggregate viewpoint, this contributes to the declining private saving rate, which brings us to the intersection between Japanese private saving and its industrial structure.

Heavy manufacturing and services in Japan are oligopolistic with close relationships between the largest groups of firms and the government. Corporate income is therefore bolstered by

\footnotetext{
${ }^{7}$ Household saving rates also fell during the stagnation period, in part due to the ageing of the population (Horioka 2006), and to rising fiscal deficits.
} 
oligopoly rents. Yet, because little net corporate income is paid out to owners in dividends and liquidation of holdings is rare at the household level, more than a fifth of GDP is saved by corporations (Bayoumi et al. 2010). Moreover, its oligopolistic structure appears to be protected by comparatively high entry and exit costs, with rates of business start-up in Japan low by OECD standards and declining (Imai and Kawagoe, 2000). It is in this context that the balance sheet recession thesis makes sense, otherwise low financing costs would encourage substantial green-field investment. This brings us back to the supply side, where the role of Japan's industrial policies is clearly distinctive and important.

Very high productivity growth in a large near-neighbour

In economic models with two trading regions it is readily seen that accelerating productivity in one region stagnates GDP in the other as savings in the other are directed to investment abroad. Income growth (GNP rather than GDP) continues in the stagnating region, albeit more slowly than in the dynamic one. This effect is muted, however, by two countervailing ones. First, the continued receipt of income from foreign investments sustains home aggregate demand and hence the output of the dominant mostly non-traded home services sector. Second, FDI into China tends to be associated with outsourcing of labour-intensive industrial components or product assembly, one consequence of which can be improvement in the productivity of the originating home industry. In any case, the scale of the effect on Japan's economy depends on the portion of its current account surplus that goes, directly or indirectly, to China (Fujiwara et al. 2008). While Ahn and Lee (2007) find supporting evidence for the case of Korea, where FDI flows to China tend to decrease local growth, we have found no research that addresses this issue directly in the case of Japan. Robertson and $\mathrm{Xu}$ (2010), however, use a retrospective dynamic model to examine the zero-China growth counterfactual. Their modelling emphasises trade interdependence of the two countries rather than the capital market effects and they find that other Asian economies benefited from Chinese growth due to its lowering of durable goods import costs. 


\section{A Multi-Region Global Dynamic Model}

A multi-region, multi-product dynamic simulation model of the world economy is used that subdivides the world into 18 regions. ${ }^{8}$ Industries are aggregated into seven sectors as indicated in Table 1, with services little traded in comparison with the others. Failures of the law of one price are represented by product differentiation, so that consumers substitute imperfectly between products from different regions. For this purpose, household and government expenditures have nested CES structures over products and services and their home and imported varieties. Production has a similarly nested CES structure over primary factors and inputs. Output in region $r$ and sector $j$ takes the form:

$$
q_{r j}=A_{r}^{R} A_{r j}^{Q}\left[\beta_{r j}^{V} V_{r j}^{-\rho_{V}}+\beta_{r j}^{Q} Q_{r j}^{-\rho_{V}}\right]^{-\frac{1}{\rho_{V}}}
$$

where $V$ is a composite of primary factors and $Q$ is a composite of intermediate inputs. $A^{R}$ is a region-specific but product generic productivity factor that enhances output in all sectors, $A^{Q}$ is a region and product specific productivity factor and $\rho_{V}$ is the CES parameter that embodies the elasticity of substitution between value added and expendable inputs. $V$ and $Q$ are then similar functions of primary factors and intermediate inputs, respectively. That for $V$ is:

$$
V_{r j}=A_{r j}^{V}\left[\sum_{k} \gamma_{r j k} f_{r j k}^{-\rho_{r j}^{F}}\right]^{-\frac{1}{\rho_{r j}^{F}}},
$$

where the primary factors are indexed as $k$ and include land, production labour, skilled or professional labour, physical capital and natural resources. $A^{V}$ is a total factor productivity coefficient. Technical change is exogenous in the model, introduced in the form shocks to $A^{V}$ based on estimates of total factor productivity performance by industry. ${ }^{9}$

Regional capital accounts are open so that regional households hold portfolios of assets that are claims over home and foreign capital. Investors in region $r$ have adaptive expectations

\footnotetext{
${ }^{8}$ The model has a common production and consumption structure with Hertel et al. (1997), Ianchovichina and McDougall (2000) and Ianchovichina and Walmsley (2010) with modifications that that represent mainly the incorporation of demographic behaviour, following Tyers and Shi (2007). The regions are Australia, North America (Canada, US, Mexico), Western Europe, Central Europe and the former Soviet Union, Japan, China, Indonesia, Other East and Southeast Asia, India, Other South Asia, Latin America, Sub-Saharan Africa, North Africa and the Middle East and the rest of the world.

${ }^{9}$ The EU KLEMS database is a key source of total factor productivity estimates. See http://www.euklems.net/, March 2008.
} 
about real net rates of return on installed capital, $r_{r}^{c}$, the determinants of which can be summarised as:

$$
r_{r}^{c}=\frac{P_{r}^{Y} M P_{r}^{K}}{P_{r}^{K}}-\delta_{r}
$$

where $P_{r}^{Y}$ is the region's GDP price, $P_{r}^{K}$ is the price of capital goods (a separate industry defined in the model), and $\delta_{r}$ is the depreciation rate. Given this rate of return the determination of investment in each region can be simply characterised as follows. Reminiscent of Tobin's Q, it is driven positively by the real net rate of return, $r_{r}^{c}$, and negatively by the rate that must be returned to savers, or the financing cost, $r_{r}$. Thus, the real volume of capital goods demanded is

$$
I_{r}=I\left(r_{r}^{c}, r_{r}\right)
$$

To arrive at $r_{r}$, a global interest rate, $r^{w}$, is first defined such that $r_{r}=r^{w}+\pi_{r}$, where $\pi_{r}$ is a usually exogenous regional interest premium, which captures the effects of capital controls in the one hand (market segmentation) and differential regional risk on the other. The global rate, $r^{w}$, and indirectly $r_{r}$, is then derived to clear the global market for financial capital:

$$
\sum_{r}\left[\sum_{g} S_{g r}\left(\frac{Y_{g r}}{N_{g r} P_{r}^{C}}, A_{r}^{S}, r_{r}\right)+\left(T_{r}-G_{r}\right)\right]=\sum_{r} P_{r}^{K} I_{r}\left(r_{r}^{c}, r_{r}\right)
$$

where the quotient is real regional income per capita for each age-gender-skill group, $g$, in region $r$ and $P_{r}^{K}$ is the regional price of capital goods. The coefficient $A^{S}$ is a group-generic shifter of savings behaviour which we use later to examine the link between aggregate performance and the saving rate. Government spending, $G$, is set to vary with endogenous revenue from direct and indirect taxes, $T$, to maintain initial fiscal deficits and surpluses as percentages of GDP.

Lagged adjustment processes embedded in the $I\left(r_{r}^{c}, r_{r}\right)$ ensure that financial capital is not sufficiently mobile internationally to equate $r_{r}^{c}$ and $r_{r}$ in the short term, but that their paths 
converge in the long term unless exogenous shocks prevent it. Baseline values of the interest premia, $\pi_{r}$, are calibrated to yield observed trends in shares of global investment. ${ }^{10}$

As in other dynamic models of the global economy, the primary endogenous component of simulated economic growth is physical capital accumulation. Growth also stems, however, from the transformation of production workers into skilled or professional workers. The characterisation of changes in labour supply and quality is via the incorporation of complete demographic behaviour. Populations in four age groups, two genders and two skill categories are tracked through time: a total of 16 population groups that constitute separate households in each defined region. The skill subdivision is between production labour (unskilled) and professional labour (skilled). ${ }^{11}$ Each age-gender-skill group is represented as a homogeneous sub-population with a group-specific birth and death rate, labour force participation rate and rates of immigration and emigration. Each group also has independent consumption-saving behaviour, which is endogenous to current real per capita income and the real home interest rate but not forward looking. ${ }^{12}$

\section{The Comparative Power of Shocks that Drive Stagnation and Recovery}

The model introduced in the previous section offers insight into each of the economic stagnation stories offered in Section 2, and their untold counterpart recovery stories. We use it to assess the comparative power of the associated shocks through the construction of elasticities of Japan's economic performance indicators to these shocks. These stem from the application of small once-and-for-all changes to determinants, such as sectoral productivity, and the charting of the dynamic consequences of each for key performance variables, like real GDP and real per capita GNP.

\footnotetext{
${ }^{10}$ The investment shares are simply extrapolated for the years beyond 2010. The risk premium for China diminishes through time in a manner considered to be due to financial reforms (Tyers and Golley 2010).

${ }^{11}$ The subdivision between production workers and professionals and para-professionals accords with the International Labour Organisation's occupation-based classification and is consistent with the labour division adopted in the GTAP Database. See Liu et al. (1998).

12 The mostly non-traded services sector is relatively intensive in skill and so trends in skill composition can prove to be particularly important determinants of both performance and the real exchange rate. Japan's already high share of skilled workers reduces the potential for skill-upgrading to contribute to its recovery so it is not experimented with here. Endogenous skill acquisition depends on the rate at which each region's education institutions transform unskilled (production-worker) families into skilled (professional-worker) families. Rates of transformation change through time in response to corresponding changes in real per capita income, the skilled wage premium and the remaining share of production worker families in each age-gender group.
} 
The supply side shocks are readily represented via the exogenous factor productivity growth rates used and via changes in the birth rate to alter population and labour force growth. The effects of the very high productivity growth in China in the 1990s and 2000s are also readily represented using the same parameters. ${ }^{13}$ Since the model is in real variables, however, home demand side shocks must be represented less directly. This is via the two key variables to emerge from the home demand side discussion in Section 2, namely the negative risk premium on Japanese domestic investment and the gross domestic saving rate. The former is exogenous and readily shocked and the latter, while endogenous to real per capita income and the interest rate at the age-gender-skill group level, can be shifted collectively to represent changes in expectations about future real disposable income.

The responses to once and for all shocks take the form of trajectories over two decades. The sizes of the elasticities thus generated vary through time, due mainly to the influence of the shocks on the global distribution of investment and its implications for subsequent capital accumulation and capital returns.

\section{Sectoral total factor productivity:}

The first set of elasticities calculated is to productivity shocks. In steady states the elasticities of a performance indicator like real GDP to sectoral total factor productivity are approximately value added shares. In the medium term, however, such productivity shocks cause transitional reallocation of global investment across regions and real exchange rate realignments. The impacts of once and for all shocks to sectoral total factor productivity, $A^{V}$ in (2), on Japanese real GDP are shown in Figure 5. Not surprisingly, service productivity proves dominant as an explanator of GDP growth, with influence that rises early on as investment is attracted into Japan and settles as the capital stock approaches a new steady state growth path. The corresponding results for Japan's real per capita income are shown in Figure 6. These show the same general pattern, albeit with slightly smaller values arising because real per capital income includes returns from investment abroad and so is less sensitive to whether saving is directed abroad or to investment at home.

\section{Birth rate:}

\footnotetext{
${ }^{13}$ Chinese productivity estimates used are those from Tyers et al. (2008), which used the same model to focus on China's real exchange rate determinants.
} 
Higher fertility in Japan cannot be expected to yield significant increases in GDP until newborns reach working age, and so there is a lagged response, as shown in Figure 7. ${ }^{14}$ Dependent children do affect real per capita income, however, and so measurable declines occur earlier, as indicated in Figure 8. That real per capita income should decline when the population increases is the familiar result from Solow-Swan type growth dynamics, driven by diminishing returns to accumulating factors (Pitchford 1974). Here it is augmented by temporarily increased dependency - a negative demographic dividend (Golley and Tyers 2011).

\section{Gross domestic saving rate:}

This is a generic once-and-for-all shock to a common coefficient of the consumption equation for each age-gender-skill group, $A^{S}$ in (5), imposed holding fiscal balance constant as a proportion of GDP and ignoring the distinction between corporate and household saving. It is to gauge the links between the average saving rate and overall performance. ${ }^{15}$ Here the result is a single per cent increase in the gross domestic saving rate, the effects of which are also shown in Figures 7 and 8. Japan's considerable home investment bias ensures that more home saving yields additional home investment but there is also an increase in "excess" saving and hence in the current account surplus. This causes a real depreciation as more domestic income creates expenditure abroad. The net effects on GDP are negligible over two decades, as the investment and net export gains are offset by the decline in consumption. The loss of saving to investment abroad does not reduce real per capita income, however, which is subsequently bolstered by increased net foreign factor income.

\section{The investment interest premium:}

The risk premium on home investment, which is discussed in Sections 2 and 3 and formulated as $\pi$ in Section 3, is negative in Japan due to home aversion to real appreciation risk. Globally, as modelled, it is a parameter that affects the distribution of invested funds directly and so Japan's share of this investment and hence its real GDP might be expected to be quite sensitive to it. To measure this effect, Japan's premium is shifted in the positive

\footnotetext{
${ }^{14}$ The transition appears in Figure 7 to occur after little more than a decade. In reality this might be thought of as due to a rising female participation rate as children reach school age, though age-specific participation rates are exogenous in this analysis. The reason it appears is the approximation of demographic behavior via four large age groups. When, for example, a higher birth rate augments the $0-15$ group at least some added survival to older age groups begins immediately.

${ }^{15}$ Consumption by household group is separately endogenous in the model but is here influenced by a shift parameter that changes the saving rate. The elasticities are then the quotients of the proportional changes to the indicator variables and those to the saving rate.
} 
direction by a single percentage point as of 2010. Once again, the effects on real GDP and real per capita income are shown in Figures 7 and 8. They are strongly negative, particularly for real GDP, with elasticities that accumulate to levels larger in magnitude than for any of the other determinants examined. Not only are these elasticities comparatively large, but the effect is long lasting. The effect on investment is of shorter duration, since a positive shift in the premium repels investment in the short term but slows growth in the capital stock, eventually raising capital returns enough to cause investment to return. As modelled, however, this process causes a longer-lasting shortfall in GDP. Again, because real per capita income captures returns from investment directed abroad, the net effect of the positive shift in the premium, shown in Figure 8, is much smaller than that on GDP.

\section{Chinese manufacturing productivity:}

The final shock is to productivity in China's manufacturing sector. Total factor productivity in both manufacturing sectors of the Chinese economy, again measured by $A^{V}$ in (2), is raised once and for all by a single per cent. The resulting elasticities are also shown in Figures 7 and 8 . The surge in Chinese productivity affects Japan's economic performance through both financial and product markets. The dominant force in the short to medium term is the redirection of investment into China from the rest of the world, including Japan. Real Japanese GDP is reduced over an extended period by the investment diversion and the increased competitiveness of China's export manufacturing sector, combined with the associated slowing in the growth of the Japanese capital stock. Again, because real income per capita captures returns from Japan's investment in China, its sensitivity to Chinese growth, though similarly signed, is much smaller.

Comparative sensitivity to shocks:

The determinants whose elasticities are presented in Figures 5-8 have influence that varies considerably in magnitude. Most sensitive is the attitude of Japan's savers to the riskiness of returns from investment abroad. The size of the negative risk premium is dominant, though it should be borne in mind that the elasticity shown is relative to a one percentage point (100 basis point) change in the home relative to the foreign long bond yield. Nonetheless, the rise in its magnitude after the large real appreciation of the late 1980s suggests that, other things equal, a period of comparative real exchange rate stability such as that since 2000 could be a cause for its erosion, along with home investment in Japan. Fortunately for Japan’s potential recovery, other things need not be equal. The other striking result that emerges is the 
prominence of services productivity in Japan's economic performance. This affects GDP via two channels: first, the dominance of services in GDP ensures a substantial direct effect but, second, services have the largest single share in capital goods production. More services productivity cheapens capital goods and further raises expected returns from investment in all sectors. This has the potential to offset any erosion that might occur in the negative risk premium. Critically, these results point to the significant role services must play in Japan's recovery.

Nonetheless, the smaller elasticity values need not be discounted since their ultimate effects depend on the magnitudes of shocks. For example, the elasticity to the saving rate is comparatively small, yet Figure 4 shows that the gross domestic saving rate fell by almost a third in the two lost decades. Similarly, the elasticities to Chinese manufacturing productivity seem small, except that the gains in China were up to or exceeding six per cent per year during this period - a total shock of near 300 per cent. ${ }^{16}$ This extraordinary growth is unlikely to be repeated in future decades, or if it is it is unlikely to be driven by manufacturing productivity. Indeed, there is much potential in China for productivity growth in services, which could drive its long term growth. This is all the more reason for Japan to improve its service productivity, since in the face of service driven growth in China, failure to do this could cause another round of real appreciations that would further hurt the Japanese economy. ${ }^{17}$

\section{Effects of the Earthquake and Tsunami}

Natural disasters are another reason why economies can stagnate, since they absorb resources that would otherwise generate growth. The tragic earthquake and tsunami of March 2011 is a case in point. A preliminary idea as to the aggregate economic impact of this shock is obtained by simulating its effect on productivity and consumption. To do this we note that the affected prefectures were not centres of manufacturing but rather dominated by services. They house 4.5 per cent of Japan’s population, suggesting a reduction of 4.5 per cent in Japan's services output with given factors of production. ${ }^{18}$ To capture the historical tendency

\footnotetext{
${ }^{16}$ For one analysis of Chinese manufacturing productivity, see Tyers et al. (2008).

${ }^{17}$ The respective roles of supply side shocks, to productivity and demographic variables, and demand side shocks, to the saving rate and investment risk premium, in shaping recent performance are only partially assessed via these elasticities. For a more complete analysis of the two "lost decades", the model is used in full decomposition experiments by Tyers (2011).

${ }^{18}$ Implying a GDP loss of 3.5 per cent, this is consistent with the initial losses estimated by the World Bank (2011) at between 2.5 and 4.0 per cent.
} 
for the Japanese to save more in times of hardship, perhaps anticipating still harder times ahead, we combine this with a rise in Japan's gross domestic saving rate of eight per cent. Both shocks are applied in full in 2011 and then are reversed to benchmark levels over the subsequent five years. ${ }^{19}$ The rise in the gross saving rate is offered notwithstanding the likely expansion of the fiscal deficit as public infrastructure is replaced, and so it could prove excessive. The effects of these shocks on Japan's economic performance are summarised in Figure 9.

The simulation shows a severe contraction in all the key performance indicators with no return to benchmarks for almost a decade. Investment still falls substantially but its eventual recovery overshoots, reflecting Japan's undercapitalisation once the shocks have abated. The real exchange rate appreciates initially as home service prices rise relative to other home and foreign product and service prices. There are no forward-looking expectations in the model and so the real appreciation does not reflect the tendency for the nominal exchange rate to appreciate as financial agents anticipate a repatriation of assets held abroad in order to pay for the recovery.

\section{Implications for Recovery Policy}

There are two strong messages from the simulation results of the previous section. First, a rise in the risk premium on Japanese investment (alternatively, a reduction in the negative value of this premium) which would encourage investment abroad at the expense of the home economy, would slow growth for an extended period. The restoration of strong growth would appear, then, to require the encouragement of domestic investment. This, in turn, necessitates a decrease in this premium (an enlargement of its negative value) as might stem from the threat of a further real appreciation. Yet much discussion in the recovery literature includes the need for a Yen depreciation, which would be seen as safe for net-saving Japan because its sovereign debt, while considerable, is denominated in Yen (Fukao 2010b). Superficially, the monetary expansion needed to achieve this would arrest home deflation, boosting export demand and employment. As the simulations show, however, by itself, a commitment to Yen depreciation would greatly reduce the appreciation risk that sustains

\footnotetext{
${ }^{19}$ The shock to services productivity also effects productivity in the capital goods sector, which is fairly intensive in construction services. We offset this to prevent a fall in capital goods productivity and so limit what is otherwise an unrealistically large short run contraction in investment.
} 
home investment at its present level. As the results presented in the previous section indicate, the resulting change in investment could be large and deleterious.

The second strong message, however, offers an alternative route to a similarly desirable outcome. "Microeconomic reforms" focussing on the service sector could significantly increase its productivity. This would have the effect of reducing the cost of home capital goods and investment. More importantly, by lowering production cost in the non-traded sector, it would depreciate the real exchange rate. And this could occur, at least in theory, without the need for a nominal depreciation, merely from a shift in the relative prices of nontraded services. The result would then not be the opposite of the real appreciations of the late 1980s and the early 1990s, depicted in Figure 3, which took the form of nominal rate changes without significant associated changes in home price levels. Yet, while the declining price level in the non-traded component of the services sector would stem from lower costs and so retain at least market capital returns, there would nonetheless be pressure on the Bank of Japan for an accommodating expansion to allow some minimal nominal depreciation. As Fukao (2010b) notes, should future Japanese governments be too weak to achieve significant fiscal consolidation, a loss of confidence in government debt could be triggered. A flight to real (property) and foreign-denominated assets would see the wrong kind of Yen depreciation and it would accompany sharp rises in interest rates that would further widen the fiscal deficit and possibly cause property lenders to default. Yet Fukao (2010a) also sees the key role of services and industrial policy reform as a route to recovery. Here we can identify the positive consequences of this for the real exchange rate by returning to our simulations. Consider the case of the sectoral productivity shocks detailed in Figures 5 and 6. From the same simulations we plot the elasticities of the Japan's real effective rate to industrial productivity shocks in Figure 10. Once again, the productivity shock to services is dominant. The short run effect of improvements in service productivity is shown to induce an inflow of investment which causes a temporary real appreciation. But the longer term effects induce a striking real effective depreciation, amounting to 1.4 percentage points for every point of comparative productivity improvement in services. Such reforms would therefore appear to have the double-barrelled effect of securing against a collapse of home investment in the 
short run and offering a substantial home relative price driven real depreciation in the longer term. $^{20}$

\section{Conclusion}

In recent decades, notwithstanding its continuing key role as global investor and trading partner, Japan's global economic footprint has contracted due to its comparative stagnation since the 1990s and, more recently, the tragic 3-11 earthquake of 2011. A brief review of the many claimed sources of Japan’s comparative stagnation highlights macroeconomic policy errors of the period which are unlikely to be repeated and the very important role played by associated supply side shocks. Most important from the perspective of Japan's recovery is the sensitivity of its overall economic performance to the productivity of its services sector and the evident room for improvement in this area. Simulations using a multi-region global dynamic model help analyse the potential sources of recovery, along with the implications of the 3-11 disaster. Both demand and supply side determinants prove important though the key role of services emerges clearly.

Post 3-11, continued austerity is unlikely to relieve pessimism about Japan’s economic performance and boost investment. A real depreciation is required and an associated export stimulus. This could be facilitated by reducing service costs to the public and to exporters, which in turn could be provided (possibly quickly in association with the 3/11 emergency) by a further opening of the home services sector to competition and inward FDI. Given the current state of other industrialised economies, mercantilism is strong and there is no capacity to shoulder the burden of Japan's recovery abroad, especially when that could lead to a permanent opening for Japanese goods not already imported by them. Yet any expansion in Japan's exports would be directed to the rapidly growing Asian economies. Moreover, at least on this occasion, a real Japanese depreciation might not be seen as a "beggar thy neighbour" step, especially if it is driven by relative price changes at home while at the same time Japan is inviting foreign firms into its hitherto protected services industries.

\footnotetext{
${ }^{20}$ The experience of Australia's "microeconomic reform" in the 1980s and 1990s is relevant here. Substantial service sector reforms there allowed real depreciations which were accommodated by price level targeting monetary policy and hence nominal depreciations (Productivity Commission 1999).
} 


\section{References:}

Ahn, S., Lee, J., 2007. Integration and Growth in East Asia, Bank of Japan Institute for Monetary and Economic Studies Discussion paper 2007-E-14.

Aloy, M., Gente, K., 2009. The Role of Demography in the Long Run Yen-USD Real Exchange Rate Appreciation. Journal of Macroeconomics 31, 654-667.

Ball, L., 2008. Helicopter Drops and Japan’s Liquidity Trap, Bank of Japan Institute for Monetary and Economic Studies Discussion Paper 2008-E-4.

Bayoumi, T., 2001. The Morning After: Explaining the Slowdown in Japanese Growth in the 1990s. Journal of International Economics 53, 241-259.

Bayoumi, T., Tong, H., Wei, S.J., 2010. The Chinese Corporate Savings Puzzle: A Firm-level Cross-country Perspective. National Bureau of Economic Research Working Paper 16432, Cambridge Massachusetts.

Beaudry, P., Collard, F., Green, D.A., 2005. Explaining Productivity Growth: the Role of Demographics. International Productivity Monitor 10, 49-65.

Beaudry, P., Portier, F., 2005. Stock Prices, Total Factor Productivity and Economic Fluctuations: Evidence from Japanese Data and US Sectoral Data. Journal of the Japanese and International Economies 19, 635-652.

Beaudry, P., Portier, F., 2006. News, Stock Prices and Economic Fluctuations. American Economic Review 96, 1293-1307.

Beaudry, P., Portier, F., 2007. When can Changes in Expectations Cause Business Cycle Fluctuations. Journal of Economic Theory 135, 458-477.

Boltho, A., Corbett, J., 2000. The Assessment: Japan's Stagnation - Can Policy Revive the Economy? Oxford Review of Economic Policy 16, 1-17.

Brown, D., Deardorff, A., Fox, A., Stern, R., 1996. The Liberalization of Services Trade: Potential Impacts in the Aftermath of the Uruguay Round, in: Martin, W., Winters, L.A. (Eds.), The Uruguay Round and the Developing Countries. Cambridge University Press, Cambridge.

Clark, G., 1978. Modern Nation Preserves Outdated Attitudes: the Key to Japan’s Economic Ills is to Correct the Inefficiency of its Tertiary Industry, The Japan Times, 23 January

Corbett, J., Ito, T., 2010. What Should the US and China Learn From the Past US-Japan Conflict?, VOX: Research-Based Policy Analysis and Commentary, www.voxeu.org, 24 November. 
Dee, P., Hardin, A., Holmes, L., 2000. Issues in the Application of CGE Models to Services Trade Liberalisation, in: Findlay, C., Warren, T. (Eds.), Impediments to Trade in Services: Measurement and Policy Implications. Routledge, London, pp. 267-286.

Economist, T., 2010. Into the Unknown: A Special Report on Japan, November 20-26 Issue, 22pp.

Eggertson, G., Ostry, J., 2005. Does Excess Liquidity Pose a Threat to Japan? International Monetary Fund Policy Discussion Paper PDP/05/5.

Fujiwara, I., Otsu, K., Saito, M., 2008. The Global Impact of Chinese Growth. Bank of Japan Institute for Monetary and Economic Studies Discussion Paper No. 08-E-22.

Fukao, M., 2010a. Service Sector Productivity in Japan: the Key to Future Economic Growth. Research Institute of Economy, Trade and Industry, IAA, Discussion Paper 10-P007.

Fukao, M., 2010b. Financial Crisis and Long Term Stagnation in Japan: Fiscal Consolidation under Deflationary Pressures. Keio-Kyoto Global Center of Excellence Discussion Paper DP2010-010.

Gadir, J., 2009. The Value of Japanese Inefficiency, NewMatilda.com.

Golley, J., Tyers, R., 2011. Contrasting Giants: Demographic Change and Economic Performance in China and India. CAMA Working Papers Research School of Economics, Australian National University.

Goyal, R., McKinnon, R.I., 2003. Japan’s Negative Risk Premium in Interest Rates: the Liquidity Trap and the Fall in Bank Lending. The World Economy 26, 339-363.

Hamada, K., Okada, Y., 2009. Monetary and International Factors behind Japan’s Lost Decade. Journal of the Japanese and International Economies 23, 200-219.

Hamao, Y., Mei, J., Xu, Y., 2007. Unique Symptoms of Japanese Stagnation: An Equity Market Perspective. Journal of Money Credit and Banking 39, 901-923.

Hayashi, F., Prescott, E.C., 2002. The 1990s in Japan: A Lost Decade. Review of Economic Dynamics 5, 206-235.

Henning, C.R., 2008. Accountability and Oversight of US Exchange Rate Policy. Peterson Institute for International Economics, Washington DC.

Hertel, T.W., 1997. Global Trade Analysis Using the GTAP Model. Cambridge University Press, New York.

Hirschmeier, J., Yui, T., 1981. The Development of Japanese Business. George Allen and Unwin, London. 
Horioka, C.Y., 2006. The Causes of Japan’s 'Lost Decade': the Role of Household Consumption. Japan and the World Economy 18, 378-400.

Hoshi, T., Kashyap, A.K., 2004. Japan’s Financial Crisis and Economic Stagnation. Journal of Economic Perspectives 18, 3-26.

Ianchovichina, E., McDougall, R., 2000. Theoretical Structure of Dynamic GTAP. GTAP Technical Paper No.17, Purdue University.

Ianchovichina, E., Walmsley, T., 2010. Dynamic Modeling and Applications in Global Economic Analysis. Cambridge University Press, Cambridge.

Imai, Y., Kawagoe, M., 2000. Business Start-ups in Japan: Problems and Policies. Oxford Review of Economic Policy 16, 114-123.

International Monetary Fund, 2006. Awash With Cash: Why Are Corporate Savings So High?, Chapter IV in World Economic Outlook, Washington DC.

Kay, C., Clark, T., 2005. Saying Yes to Japan: How Outsiders are Reviving a Trillion Dollar Services Market. Vertical Inc, New York.

Kobayashi, K., Inada, M., 2005. Business Cycle Accounting for the Japanese Economy. The Research Institute of Economy, Trade and Industry, Tokyo, Japan.

Koo, R.C., 2003. Balance Sheet Recession: Japan’s Struggle with Uncharted Economics and its Global Implications. John Wiley and Sons, Clementi Loop, Singapore.

Koo, R.C., 2009. The Holy Grail of Macroeconomics: Lessons from Japan’s Great Recession, revised edition. John Wiley and Sons, Singapore.

Krugman, P.R., 1998. It’s Baaack: Japan's Slump and the Return of the Liquidity Trap. Brookings Papers on Economic Activity 2, 137-205.

Lincoln, E.J., 1988. Japan: Facing Economic Maturity. The Brookings Institution, Washington DC.

Liu, J., Leeuwen, N.V., Vo, T.T., Tyers, R., Hertel, T.W., 1998. Disaggregating Labor Payments by Skill Level in GTAP, Technical Paper No.11. Center for Global Trade Analysis, Purdue University, West Lafayette.

McKinnon, R., Ohno, K., 2001. The Foreign Exchange Origins of Japan’s Economic Slump and Low Interest Liquidity Trap. The World Economy 24, 279-315.

Miyao, R., 2006. Nihon keizai no hendou youin: seisansei shokku no yakuwari (Causes of Fluctuations in the Japanese Economy: The Role of Productivity Shocks), Bank of Japan Working Paper Series 06-J-1 (in Japanese).

Morana, C., 2004. The Japanese Stagnation: An Assessment of the Productivity Slowdown Hypothesis. Japan and the World Economy 16, 193-211. 
Obstfeld, M., 2009. Time of Troubles: the Yen and Japan’s Economy, 1985-2008. National Bureau of Economic Research Working Paper 14816, Cambridge, Massachusetts.

Peri, G., 2010. The Effect of Immigration on Productivity: Evidence from the United States. National Bureau of Economic Research Working Paper 15507, Cambridge, Massachusetts.

Pitchford, J.D., 1974. Population in Economic Growth. North Holland Publishing Co., Amsterdam.

Posen, A.S., 1998. Restoring Japan’s Economic Growth. Institute for International Economics, Washington, DC.

Productivity Commission, 1999. Microeconomic Reforms and Australian Productivity: Exploring the Links. Government of Australia, Canberra.

Ramaswamy, R., Rendu, C., 1999. Japan’s Stagnant Nineties - A Vector Autoregression Perspective. International Monetary Fund Working Paper WP-99-45.

Robertson, P.E., Xu, J.Y., 2010. In China’s Wake: Has Asia Gained from China’s Growth? The World Economy Forthcoming.

Saito, M., 2000. The Japanese Economy. World Scientific, Singapore.

Taylor, J.B., 2006. Lessons From the Recovery From the 'Lost Decade’ in Japan: the Case of the Great Intervention and Monetary Injection. Background Paper for the International Conference of the Economics and Social Research Institute, Cabinet Office, Government of Japan, September.

Taylor, J.B., 2007. Global Financial Warriors: the Untold Story of International Finance in the Post 9/11 World. W.W. Norton, New York.

Tyers, R., 2011. Global Implications of Japanese Economic Stagnation, CAMA Working Papers. Australian National University, Canberra.

Tyers, R., Corbett, J., 2011. Japanese Economic Performance: A Survey of Quantitative Analyses and Implications for Australia, Working Paper. Crawford School, Australian National University, Canberra.

Tyers, R., Golley, J., 2010. China's Growth to 2030: The Roles of Demographic Change and Investment Premia. Review of Development Economics 14, 592-610.

Tyers, R., Golley, J., Bu, Y., Bain, I., 2008. China’s Economic Growth and its Real Exchange Rate. China Economic Journal 1, 123 - 145.

Tyers, R., Shi, Q., 2007. Global Demographic Change, Policy Responses and Their Economic Implications. The World Economy 30, 537-566. 
Wilson, D., 2000. Japan’s Slow-down: Monetary versus Real Explanations. Oxford Review of Economic Policy 16, 18-33.

World Bank, 2011. The Recent Earthquake and Tsunami in Japan: Implications for East Asia, East Asia and Pacific Economic Update.

Yoshikawa, H., 2000. Technical Progress and the Growth of the Japanese Economy, Past and Future. Oxford Review of Economic Policy 16, 34-45. 
Table 1: Product Composition

\begin{tabular}{ll}
\hline Product aggregate & Composition \\
\hline Agriculture & paddy rice, wheat, other cereal grains, vegetables, \\
& fruit, nuts, oil seeds, sugar cane, sugar beet, plant- \\
& based fibres, other crops, bovine cattle, sheep and \\
& goats, horses, other animal products, raw milk, \\
& wool, silk-worm cocoons, forestry, fishing \\
bovine cattle, sheep and goat meat products, meat \\
products, vegetable oils and fats, dairy products, \\
processed rice, sugar, other food products, \\
beverages and tobacco products, textiles, wearing \\
apparel, leather products, wood products, paper \\
products, publishing \\
chemical, rubber, plastic products, motor vehicles \\
and parts, other transport equipment, electronic \\
equipment, other machinery and equipment, other \\
meavy Manufacturing \\
metals \\
ferrous metals, other metals, metal products \\
coal, oil, gas, petroleum, coal products, gas \\
manufacture, distribution \\
minerals and mineral products not elsewhere \\
indicated \\
Serals \\
electricity, water, construction, trade, water \\
transport, air transport, other transport services, \\
communication, insurance, other financial services, \\
business services, recreational and other services, \\
public admin. and defence, education, health, \\
ownership of dwellings
\end{tabular}

Source: The GTAP Global Database, Version 5. 
Figure 1: Japan's Nominal and Real GDP ${ }^{\mathrm{a}}$

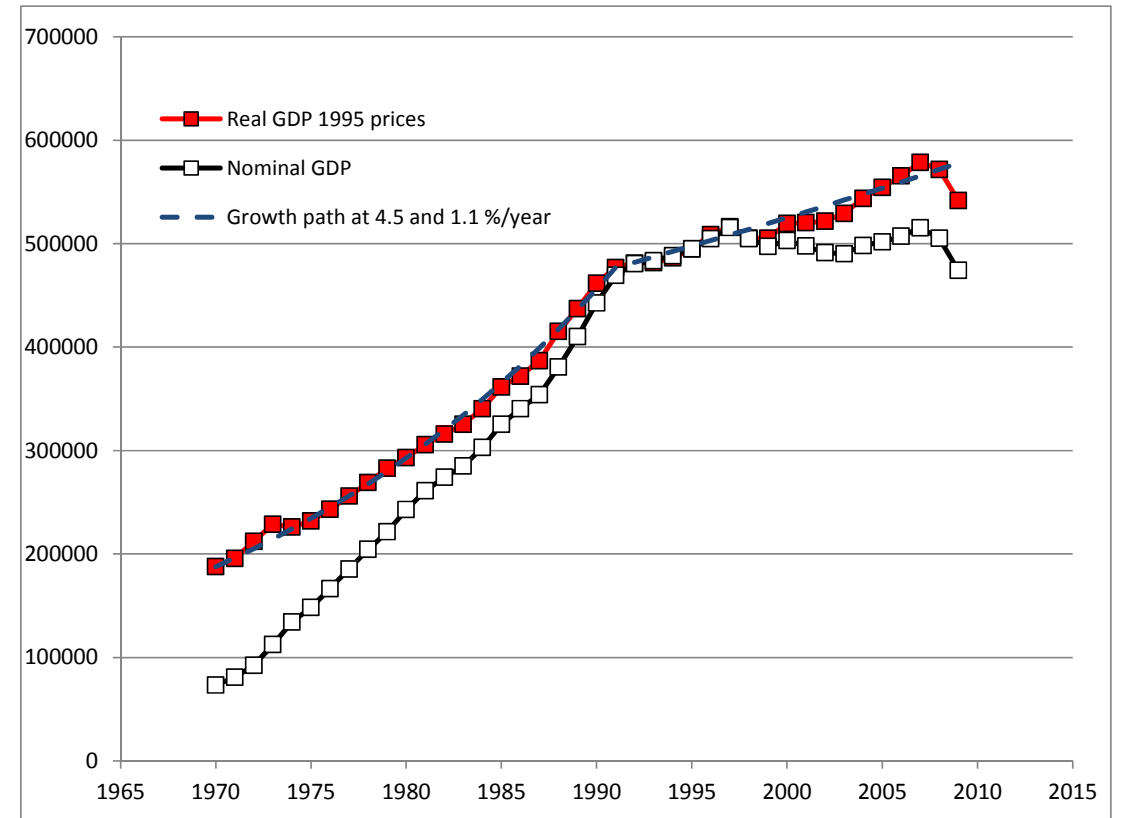

a Here Japan's nominal GDP in Yen is deflated by its GDP deflator with 1995=1.0. Source: IMF, International Financial Statistics.

\section{Figure 2: Measured Total Factor Productivity in Japan ${ }^{\text {a }}$}

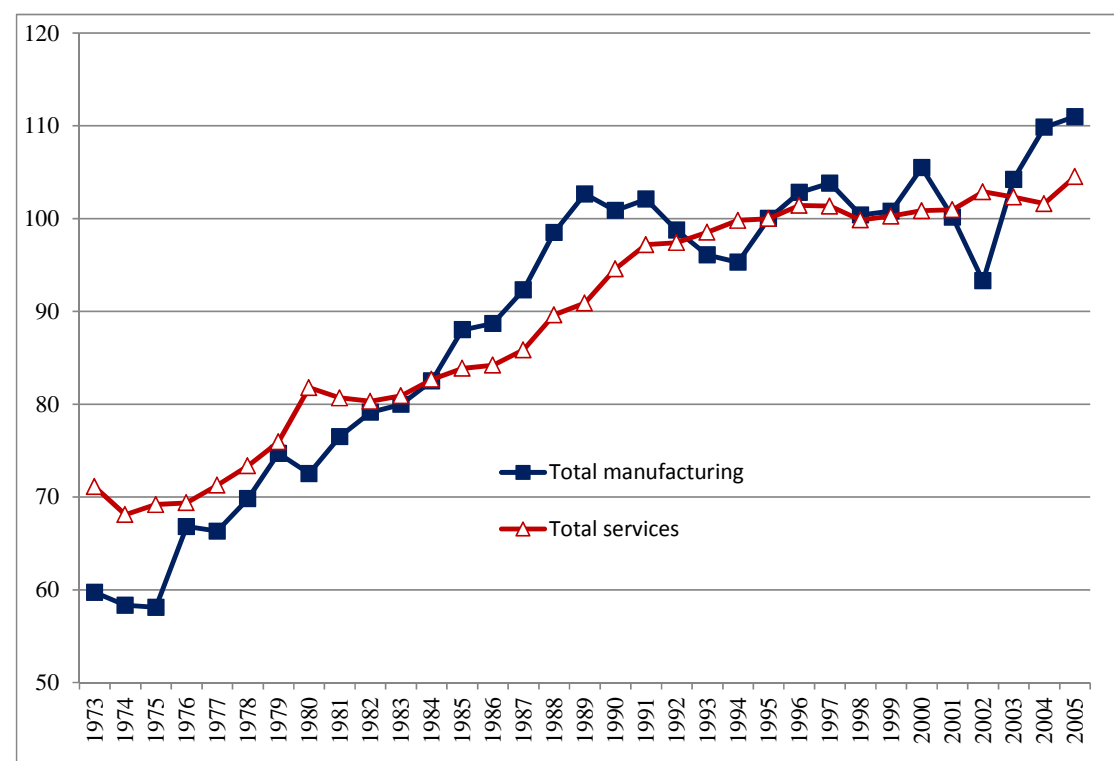

a These are indices of Japanese total factor productivity, 1995=100. Sectoral value-added productivity figures are constructed from less aggregated industry data using Törnqvist indices with value added weights.

Source: EU KLEMS database (http://www.euklems.net/, March 2008). 


\section{Figure 3: Japan's Real Exchange Rate against the United States ${ }^{a}$}

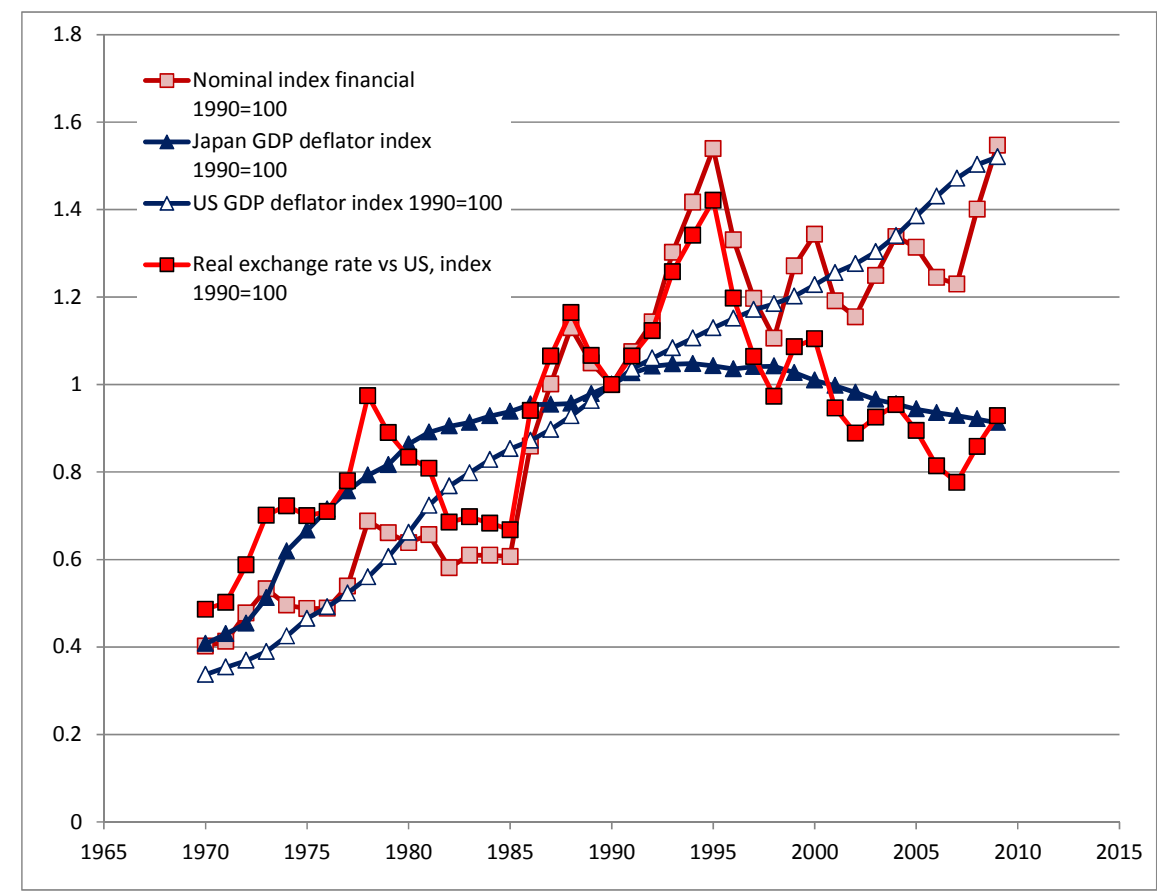

a Here the exchange rates are defined financially, so that appreciations are increases, and the real exchange rate is the nominal times the home GDP price divided by the foreign GDP price. Sources: IMF, International Financial Statistics, various issues.

\section{Figure 4: Saving and Investment in Japan ${ }^{\mathrm{a}}$}

As \% of Japan's GDP.

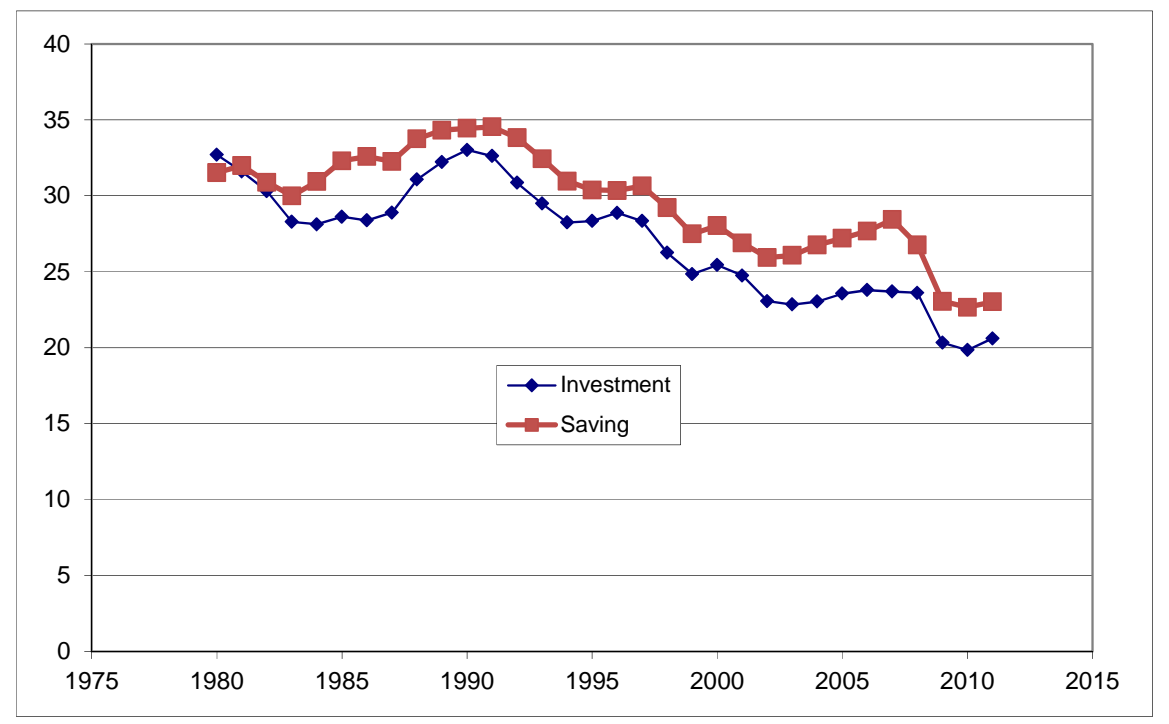

a Saving covers households corporations and government and so is adjusted for fiscal deficits. Source: IMF, International Financial Statistics. 


\section{Figure 5: Elasticities of Japan's Real GDP to Productivity Shocks ${ }^{\text {a }}$}

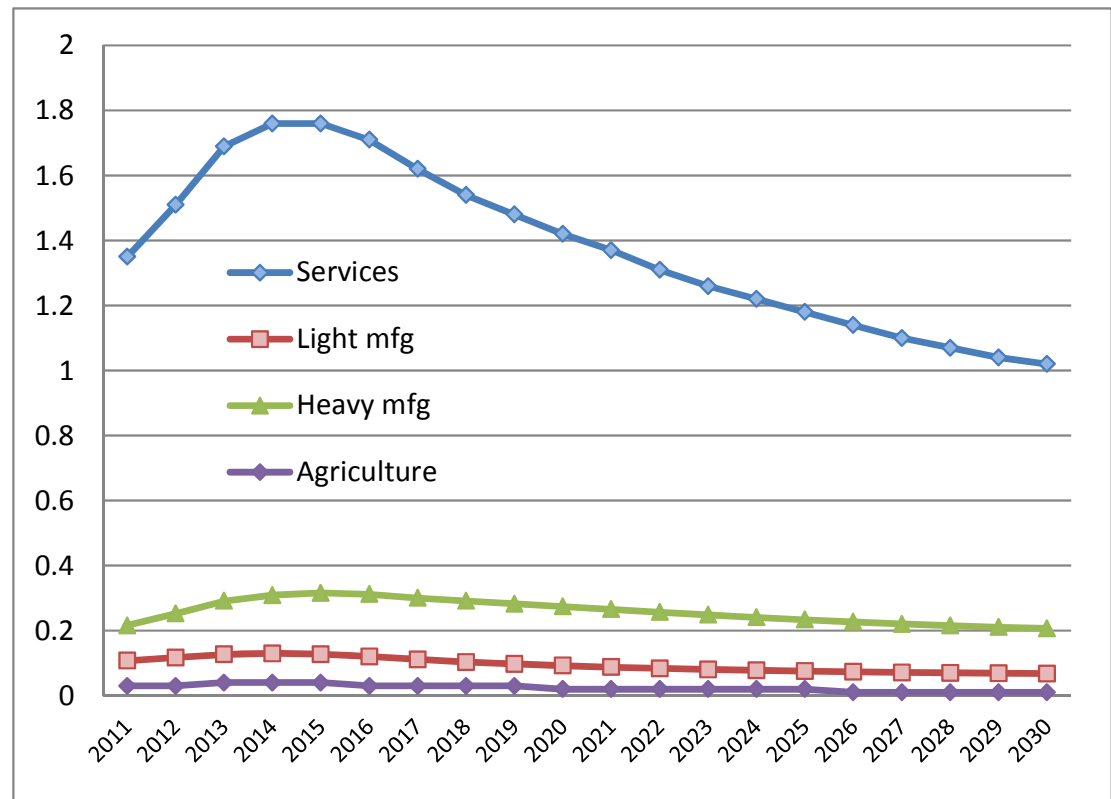

a Here a once and for all one per cent rise in the level of sectoral total factor productivity is imposed in 2011. The graph shows the subsequent path of real GDP in cumulative per cent deviations from a baseline simulation. These deviations are then elasticities of response.

Source: Simulations of the model described in the text.

\section{Figure 6: Elasticities of Japan's Real Per Capita Income to Productivity Shocks ${ }^{\text {a }}$}

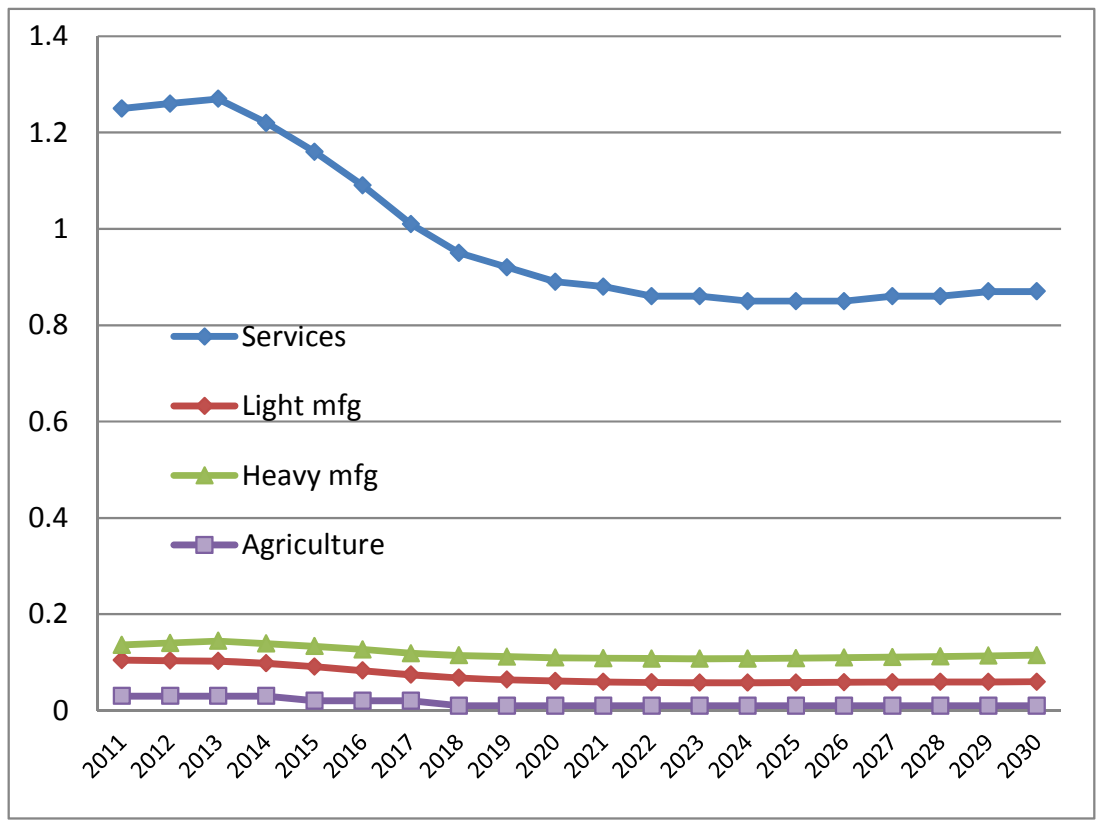

a Here a once and for all one per cent rise in the level of sectoral total factor productivity is imposed in 2011. The graph shows the subsequent path of the real per capita income in cumulative per cent deviations from a baseline simulation. These deviations are then elasticities of response. Source: Simulations of the model described in the text. 


\section{Figure 7: Elasticities of Japan's Real GDP to Other Shocks ${ }^{\mathrm{a}}$}

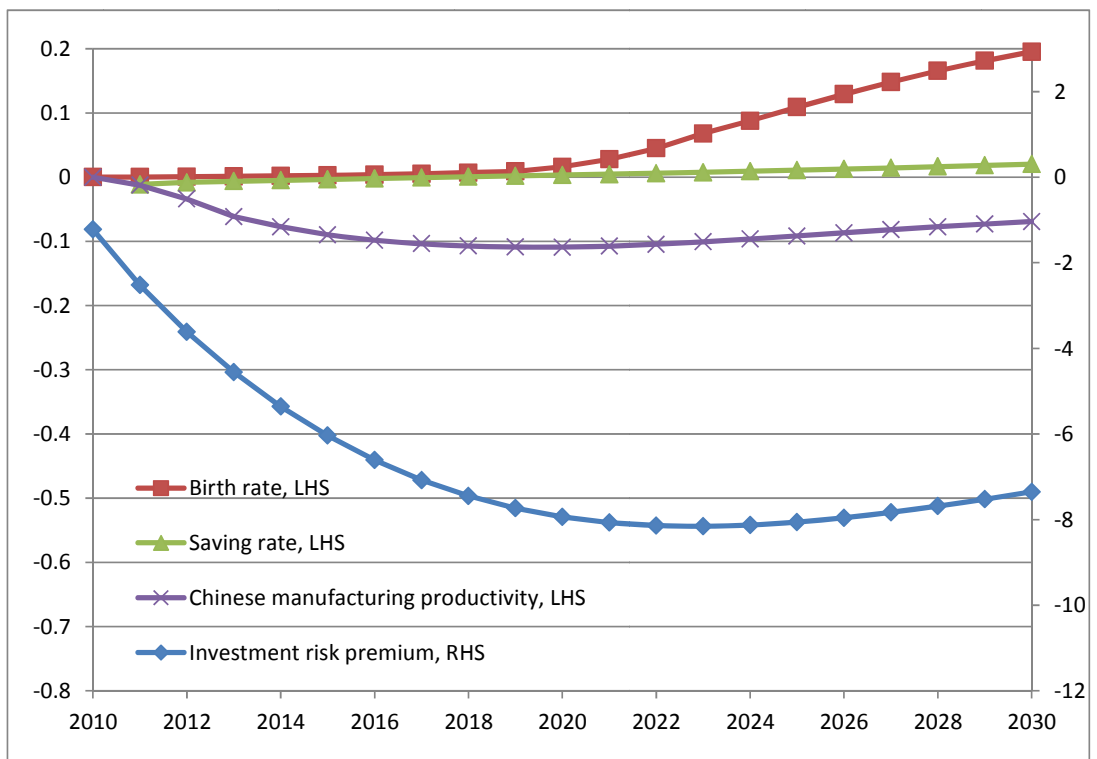

a Here a once and for all one per cent rise in the level path of the nominated variable is imposed, commencing in 2010. The graph shows the subsequent path of real GDP in cumulative per cent deviations from a baseline simulation. These deviations are then elasticities of response. The only exception to this pattern is the saving rate, which is separately endogenous for each age-gender-skill group. In this case a shift is introduced in the consumption equations and the resulting per cent changes in real GDP are divided by the corresponding change in the endogenous saving rate.

Source: Simulations of the model described in the text.

\section{Figure 8: Elasticities of Japan's Real per Capita Income to Other Shocks ${ }^{\mathrm{a}}$}

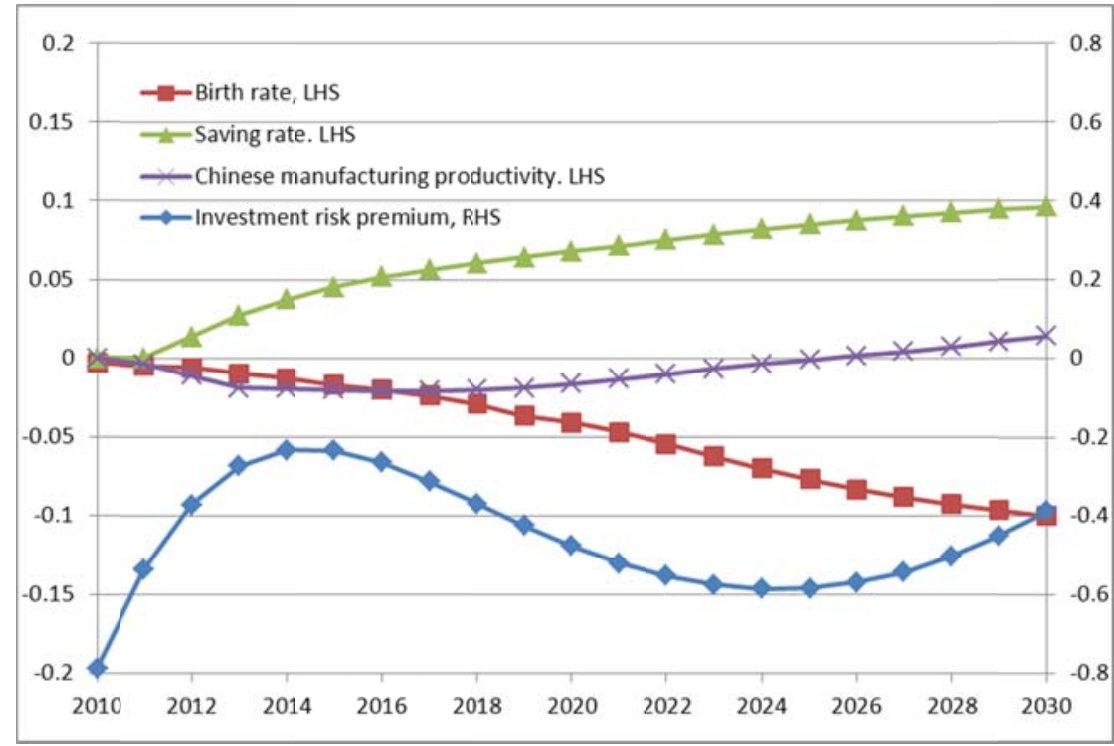

a Here a once and for all one per cent rise in the level path of the nominated variable is imposed, commencing in 2010. The graph shows the subsequent path of real income per capita in cumulative per cent deviations from a baseline simulation. These deviations are then elasticities of response. The only exception to this pattern is the saving rate, which is separately endogenous for each age-genderskill group. In this case a shift is introduced in the consumption equations and the resulting per cent changes in real income per capita are divided by the corresponding change in the endogenous saving rate.

Source: Simulations of the model described in the text. 


\section{Figure 9: Simulated Effects of the March Earthquake on Japan's Economic Performance $^{\mathrm{a}}$}

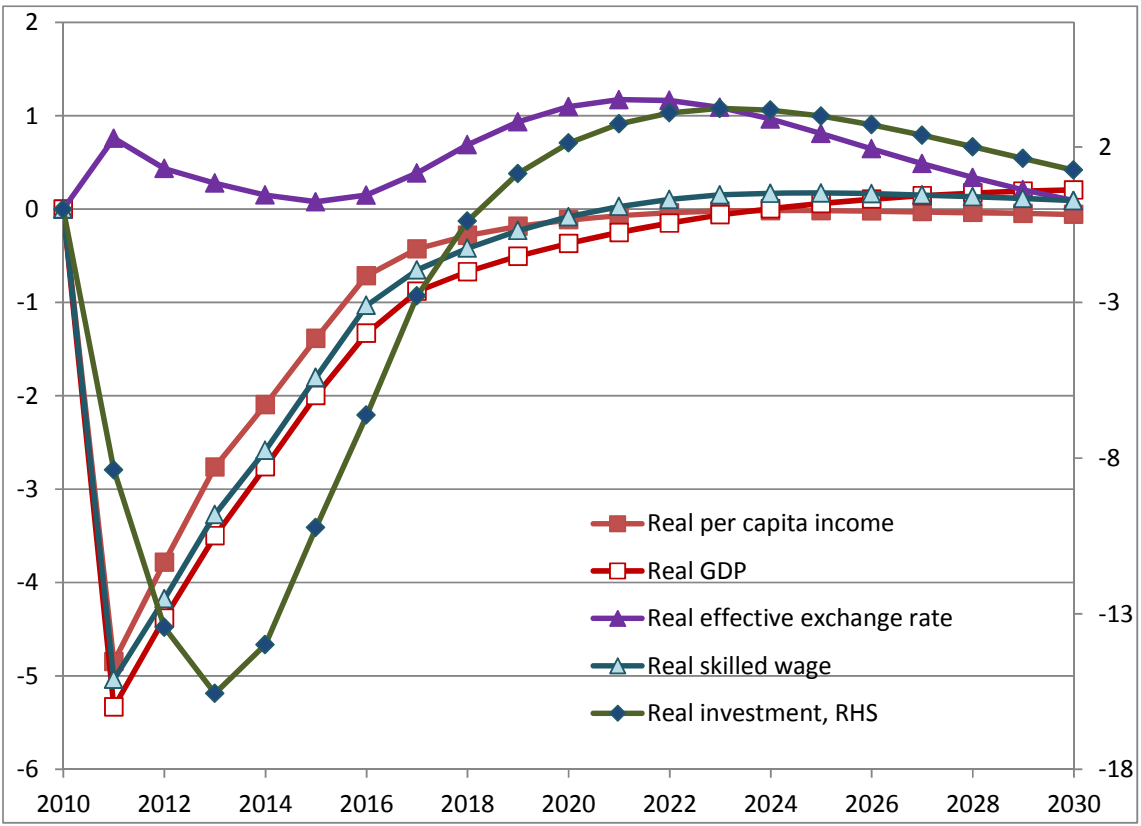

a This shows per cent departures from a baseline simulation due to the March 2011 earthquake and tsunami in Northern Honshu. Note that the fall in private investment is comparatively large and so it is shown in the RHS.

Source: Simulations of the model described in the text.

Figure 10: Elasticities of Japan's Real Effective Exchange Rate to Productivity Shocks ${ }^{a}$

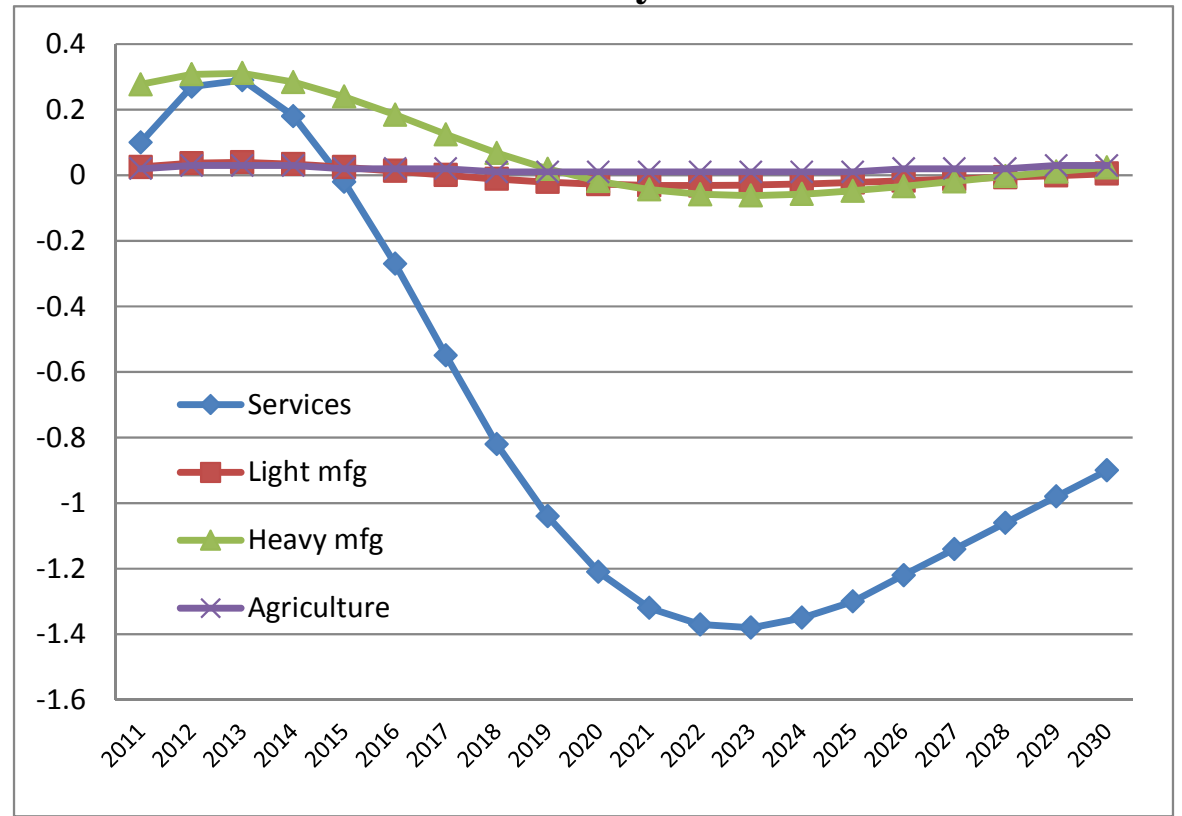

a Here a once and for all one per cent rise in the level of sectoral total factor productivity is imposed in 2011. The graph shows the subsequent path of the real effective exchange rate in cumulative per cent deviations from a baseline simulation. These deviations are then elasticities of response. Source: Simulations of the model described in the text. 


\begin{tabular}{|c|c|c|}
\hline \multicolumn{3}{|c|}{$\begin{array}{c}\text { ECONOMICS DISCUSSION PAPERS } \\
2009\end{array}$} \\
\hline $\begin{array}{l}\text { DP } \\
\text { NUMBER }\end{array}$ & AUTHORS & TITLE \\
\hline 09.01 & Le, A.T. & $\begin{array}{l}\text { ENTRY INTO UNIVERSITY: ARE THE CHILDREN OF } \\
\text { IMMIGRANTS DISADVANTAGED? }\end{array}$ \\
\hline 09.02 & Wu, Y. & CHINA'S CAPITAL STOCK SERIES BY REGION AND SECTOR \\
\hline 09.03 & Chen, M.H. & $\begin{array}{l}\text { UNDERSTANDING WORLD COMMODITY PRICES RETURNS, } \\
\text { VOLATILITY AND DIVERSIFACATION }\end{array}$ \\
\hline 09.04 & Velagic, R. & UWA DISCUSSION PAPERS IN ECONOMICS: THE FIRST 650 \\
\hline 09.05 & McLure, M. & $\begin{array}{l}\text { ROYALTIES FOR REGIONS: ACCOUNTABILITY AND } \\
\text { SUSTAINABILITY }\end{array}$ \\
\hline 09.06 & Chen, A. and Groenewold, N. & $\begin{array}{l}\text { REDUCING REGIONAL DISPARITIES IN CHINA: AN } \\
\text { EVALUATION OF ALTERNATIVE POLICIES }\end{array}$ \\
\hline 09.07 & Groenewold, N. and Hagger, A. & $\begin{array}{l}\text { THE REGIONAL ECONOMIC EFFECTS OF IMMIGRATION: } \\
\text { SIMULATION RESULTS FROM A SMALL CGE MODEL. }\end{array}$ \\
\hline 09.08 & Clements, K. and Chen, D. & AFFLUENCE AND FOOD: SIMPLE WAY TO INFER INCOMES \\
\hline 09.09 & Clements, K. and Maesepp, M. & A SELF-REFLECTIVE INVERSE DEMAND SYSTEM \\
\hline 09.10 & Jones, C. & $\begin{array}{l}\text { MEASURING WESTERN AUSTRALIAN HOUSE PRICES: } \\
\text { METHODS AND IMPLICATIONS }\end{array}$ \\
\hline 09.11 & Siddique, M.A.B. & $\begin{array}{l}\text { WESTERN AUSTRALIA-JAPAN MINING CO-OPERATION: AN } \\
\text { HISTORICAL OVERVIEW }\end{array}$ \\
\hline 09.12 & Weber, E.J. & $\begin{array}{l}\text { PRE-INDUSTRIAL BIMETALLISM: THE INDEX COIN } \\
\text { HYPTHESIS }\end{array}$ \\
\hline 09.13 & McLure, M. & $\begin{array}{l}\text { PARETO AND PIGOU ON OPHELIMITY, UTILITY AND } \\
\text { WELFARE: IMPLICATIONS FOR PUBLIC FINANCE }\end{array}$ \\
\hline 09.14 & Weber, E.J. & $\begin{array}{l}\text { WILFRED EDWARD GRAHAM SALTER: THE MERITS OF A } \\
\text { CLASSICAL ECONOMIC EDUCATION }\end{array}$ \\
\hline 09.15 & Tyers, R. and Huang, L. & $\begin{array}{l}\text { COMBATING CHINA'S EXPORT CONTRACTION: FISCAL } \\
\text { EXPANSION OR ACCELERATED INDUSTRIAL REFORM }\end{array}$ \\
\hline 09.16 & $\begin{array}{l}\text { Zweifel, P., Plaff, D. and } \\
\text { Kühn, J. }\end{array}$ & $\begin{array}{l}\text { IS REGULATING THE SOLVENCY OF BANKS COUNTER- } \\
\text { PRODUCTIVE? }\end{array}$ \\
\hline 09.17 & Clements, K. & THE PHD CONFERENCE REACHES ADULTHOOD \\
\hline 09.18 & McLure, M. & $\begin{array}{l}\text { THIRTY YEARS OF ECONOMICS: UWA AND THE WA } \\
\text { BRANCH OF THE ECONOMIC SOCIETY FROM } 1963 \text { TO } 1992\end{array}$ \\
\hline 09.19 & Harris, R.G. and Robertson, P. & $\begin{array}{l}\text { TRADE, WAGES AND SKILL ACCUMULATION IN THE } \\
\text { EMERGING GIANTS }\end{array}$ \\
\hline 09.20 & $\begin{array}{l}\text { Peng, J., Cui, J., Qin, F. and } \\
\text { Groenewold, N. }\end{array}$ & STOCK PRICES AND THE MACRO ECONOMY IN CHINA \\
\hline 09.21 & Chen, A. and Groenewold, N. & $\begin{array}{l}\text { REGIONAL EQUALITY AND NATIONAL DEVELOPMENT IN } \\
\text { CHINA: IS THERE A TRADE-OFF? }\end{array}$ \\
\hline
\end{tabular}


ECONOMICS DISCUSSION PAPERS

2010

\begin{tabular}{|c|c|c|}
\hline $\begin{array}{l}\text { DP } \\
\text { NUMBER }\end{array}$ & AUTHORS & TITLE \\
\hline 10.01 & Hendry, D.F. & $\begin{array}{l}\text { RESEARCH AND THE ACADEMIC: A TALE OF } \\
\text { TWO CULTURES }\end{array}$ \\
\hline 10.02 & McLure, M., Turkington, D. and Weber, E.J. & A CONVERSATION WITH ARNOLD ZELLNER \\
\hline 10.03 & $\begin{array}{l}\text { Butler, D.J., Burbank, V.K. and } \\
\text { Chisholm, J.S. }\end{array}$ & $\begin{array}{l}\text { THE FRAMES BEHIND THE GAMES: PLAYER'S } \\
\text { PERCEPTIONS OF PRISONER'S DILEMMA, } \\
\text { CHICKEN, DICTATOR, AND ULTIMATUM GAMES }\end{array}$ \\
\hline 10.04 & Harris, R.G., Robertson, P.E. and Xu, J.Y. & $\begin{array}{l}\text { THE INTERNATIONAL EFFECTS OF CHINA'S } \\
\text { GROWTH, TRADE AND EDUCATION BOOMS }\end{array}$ \\
\hline 10.05 & Clements, K.W., Mongey, S. and Si, J. & $\begin{array}{l}\text { THE DYNAMICS OF NEW RESOURCE PROJECTS } \\
\text { A PROGRESS REPORT }\end{array}$ \\
\hline 10.06 & Costello, G., Fraser, P. and Groenewold, N. & $\begin{array}{l}\text { HOUSE PRICES, NON-FUNDAMENTAL } \\
\text { COMPONENTS AND INTERSTATE SPILLOVERS: } \\
\text { THE AUSTRALIAN EXPERIENCE }\end{array}$ \\
\hline 10.07 & Clements, K. & $\begin{array}{l}\text { REPORT OF THE } 2009 \text { PHD CONFERENCE IN } \\
\text { ECONOMICS AND BUSINESS }\end{array}$ \\
\hline 10.08 & Robertson, P.E. & $\begin{array}{l}\text { INVESTMENT LED GROWTH IN INDIA: HINDU } \\
\text { FACT OR MYTHOLOGY? }\end{array}$ \\
\hline 10.09 & Fu, D., Wu, Y. and Tang, Y. & $\begin{array}{l}\text { THE EFFECTS OF OWNERSHIP STRUCTURE AND } \\
\text { INDUSTRY CHARACTERISTICS ON EXPORT } \\
\text { PERFORMANCE }\end{array}$ \\
\hline 10.10 & Wu, Y. & $\begin{array}{l}\text { INNOVATION AND ECONOMIC GROWTH IN } \\
\text { CHINA }\end{array}$ \\
\hline 10.11 & Stephens, B.J. & $\begin{array}{l}\text { THE DETERMINANTS OF LABOUR FORCE } \\
\text { STATUS AMONG INDIGENOUS AUSTRALIANS }\end{array}$ \\
\hline 10.12 & Davies, $\mathrm{M}$. & $\begin{array}{l}\text { FINANCING THE BURRA BURRA MINES, SOUTH } \\
\text { AUSTRALIA: LIQUIDITY PROBLEMS AND } \\
\text { RESOLUTIONS }\end{array}$ \\
\hline 10.13 & Tyers, R. and Zhang, Y. & APPRECIATING THE RENMINBI \\
\hline 10.14 & Clements, K.W., Lan, Y. and Seah, S.P. & $\begin{array}{l}\text { THE BIG MAC INDEX TWO DECADES ON } \\
\text { AN EVALUATION OF BURGERNOMICS }\end{array}$ \\
\hline 10.15 & Robertson, P.E. and Xu, J.Y. & $\begin{array}{l}\text { IN CHINA'S WAKE: } \\
\text { HAS ASIA GAINED FROM CHINA'S GROWTH? }\end{array}$ \\
\hline 10.16 & Clements, K.W. and Izan, H.Y. & $\begin{array}{l}\text { THE PAY PARITY MATRIX: A TOOL FOR } \\
\text { ANALYSING THE STRUCTURE OF PAY }\end{array}$ \\
\hline 10.17 & Gao, G. & WORLD FOOD DEMAND \\
\hline 10.18 & Wu, Y. & $\begin{array}{l}\text { INDIGENOUS INNOVATION IN CHINA: } \\
\text { IMPLICATIONS FOR SUSTAINABLE GROWTH }\end{array}$ \\
\hline 10.19 & Robertson, P.E. & DECIPHERING THE HINDU GROWTH EPIC \\
\hline 10.20 & Stevens, G. & $\begin{array}{l}\text { RESERVE BANK OF AUSTRALIA-THE ROLE OF } \\
\text { FINANCE }\end{array}$ \\
\hline 10.21 & Widmer, P.K., Zweifel, P. and Farsi, M. & $\begin{array}{l}\text { ACCOUNTING FOR HETEROGENEITY IN THE } \\
\text { MEASUREMENT OF HOSPITAL PERFORMANCE }\end{array}$ \\
\hline 10.22 & McLure, M. & $\begin{array}{l}\text { ASSESSMENTS OF A. C. PIGOU'S FELLOWSHIP } \\
\text { THESES }\end{array}$ \\
\hline
\end{tabular}




\begin{tabular}{|l|l|l|}
\hline 10.23 & Poon, A.R. & $\begin{array}{l}\text { THE ECONOMICS OF NONLINEAR PRICING: } \\
\text { EVIDENCE FROM AIRFARES AND GROCERY } \\
\text { PRICES }\end{array}$ \\
\hline 10.24 & Halperin, D. & $\begin{array}{l}\text { FORECASTING METALS RETURNS: A BAYESIAN } \\
\text { DECISION THEORETIC APPROACH }\end{array}$ \\
\hline 10.25 & Clements, K.W. and Si. J. & $\begin{array}{l}\text { THE INVESTMENT PROJECT PIPELINE: COST } \\
\text { ESCALATION, LEAD-TIME, SUCCESS, FAILURE } \\
\text { AND SPEED }\end{array}$ \\
\hline 10.26 & Chen, A., Groenewold, N. and Hagger, A.J. & $\begin{array}{l}\text { THE REGIONAL ECONOMIC EFFECTS OF A } \\
\text { REDUCTION IN CARBON EMISSIONS }\end{array}$ \\
\hline 10.27 & $\begin{array}{l}\text { Siddique, A., Selvanathan, E.A. and } \\
\text { Selvanathan, S. }\end{array}$ & $\begin{array}{l}\text { REMITTANCES AND ECONOMIC GROWTH: } \\
\text { EMPIRICAL EVIDENCE FROM BANGLADESH, } \\
\text { INDIA AND SRI LANKA }\end{array}$ \\
\hline
\end{tabular}


ECONOMICS DISCUSSION PAPERS

2011

\begin{tabular}{|c|c|c|}
\hline $\begin{array}{l}\text { DP } \\
\text { NUMBER }\end{array}$ & AUTHORS & TITLE \\
\hline 11.01 & Robertson, P.E. & $\begin{array}{l}\text { DEEP IMPACT: CHINA AND THE WORLD } \\
\text { ECONOMY }\end{array}$ \\
\hline 11.02 & Kang, C. and Lee, S.H. & $\begin{array}{l}\text { BEING KNOWLEDGEABLE OR SOCIABLE? } \\
\text { DIFFERENCES IN RELATIVE IMPORTANCE OF } \\
\text { COGNITIVE AND NON-COGNITIVE SKILLS }\end{array}$ \\
\hline 11.03 & Turkington, D. & DIFFERENT CONCEPTS OF MATRIX CALCULUS \\
\hline 11.04 & Golley, J. and Tyers, R. & $\begin{array}{l}\text { CONTRASTING GIANTS: DEMOGRAPHIC CHANGE } \\
\text { AND ECONOMIC PERFORMANCE IN CHINA AND } \\
\text { INDIA }\end{array}$ \\
\hline 11.05 & Collins, J., Baer, B. and Weber, E.J. & $\begin{array}{l}\text { ECONOMIC GROWTH AND EVOLUTION: } \\
\text { PARENTAL PREFERENCE FOR QUALITY AND } \\
\text { QUANTITY OF OFFSPRING }\end{array}$ \\
\hline 11.06 & Turkington, D. & $\begin{array}{l}\text { ON THE DIFFERENTIATION OF THE LOG } \\
\text { LIKELIHOOD FUNCTION USING MATRIX } \\
\text { CALCULUS }\end{array}$ \\
\hline 11.07 & Groenewold, N. and Paterson, J.E.H. & $\begin{array}{l}\text { STOCK PRICES AND EXCHANGE RATES IN } \\
\text { AUSTRALIA: ARE COMMODITY PRICES THE } \\
\text { MISSING LINK? }\end{array}$ \\
\hline 11.08 & Chen, A. and Groenewold, N. & $\begin{array}{l}\text { REDUCING REGIONAL DISPARITIES IN CHINA: IS } \\
\text { INVESTMENT ALLOCATION POLICY EFFECTIVE? }\end{array}$ \\
\hline 11.09 & Williams, A., Birch, E. and Hancock, P. & $\begin{array}{l}\text { THE IMPACT OF ON-LINE LECTURE RECORDINGS } \\
\text { ON STUDENT PERFORMANCE }\end{array}$ \\
\hline 11.10 & Pawley, J. and Weber, E.J. & $\begin{array}{l}\text { INVESTMENT AND TECHNICAL PROGRESS IN THE } \\
\text { G7 COUNTRIES AND AUSTRALIA }\end{array}$ \\
\hline 11.11 & Tyers, R. & $\begin{array}{l}\text { AN ELEMENTAL MACROECONOMIC MODEL FOR } \\
\text { APPLIED ANALYSIS AT UNDERGRADUATE LEVEL }\end{array}$ \\
\hline 11.12 & Clements, K.W. and Gao, G. & QUALITY, QUANTITY, SPENDING AND PRICES \\
\hline 11.13 & Tyers, R. and Zhang, Y. & $\begin{array}{l}\text { JAPAN'S ECONOMIC RECOVERY: INSIGHTS FROM } \\
\text { MULTI-REGION DYNAMICS }\end{array}$ \\
\hline 11.14 & McLure, M. & A. C. PIGOU'S REJECTION OF PARETO'S LAW \\
\hline 11.15 & Kristoffersen, I. & $\begin{array}{l}\text { THE SUBJECTIVE WELLBEING SCALE: HOW } \\
\text { REASONABLE IS THE CARDINALITY } \\
\text { ASSUMPTION? }\end{array}$ \\
\hline 11.16 & Clements, K.W., Izan, H.Y. and Lan, Y. & VOLATILITY AND STOCK PRICE INDEXES \\
\hline 11.17 & Parkinson, M. & $\begin{array}{l}\text { SHANN MEMORIAL LECTURE 2011: SUSTAINABLE } \\
\text { WELLBEING - AN ECONOMIC FUTURE FOR } \\
\text { AUSTRALIA }\end{array}$ \\
\hline
\end{tabular}

